\title{
Seasonal Variations of Carbon Dioxide, Water Vapor and Energy Fluxes in Tropical Indian Mangroves
}

\author{
Suraj Reddy Rodda *, Kiran Chand Thumaty, Chandra Shekhar Jha and Vinay Kumar Dadhwal \\ National Remote Sensing Centre (I.S.R.O), Balanagar, Hyderabad PIN 500 037, India; \\ trkchand@gmail.com (K.C.T.); chandra.s.jha@gmail.com (C.S.J.); dadhwalvk@hotmail.com (V.K.D.) \\ * Correspondence: suraj.nrsc@gmail.com; Tel.: +9140-2388-4219; Fax: +9140-2387-5932 \\ Academic Editor: Mark E. Harmon \\ Received: 31 August 2015; Accepted: 20 January 2016; Published: 6 February 2016
}

\begin{abstract}
We present annual estimates of the net ecosystem exchange (NEE) of carbon dioxide $\left(\mathrm{CO}_{2}\right)$ accumulated over one annual cycle (April 2012 to March 2013) in the world's largest mangrove ecosystem, Sundarbans (India), using the eddy covariance method. An eddy covariance flux tower was established in April 2012 to study the seasonal variations of carbon dioxide fluxes due to soil and vegetation-atmosphere interactions. The half-hourly maximum of the net ecosystem exchange (NEE) varied from $-6 \mu \mathrm{mol} \cdot \mathrm{m}^{-2} \cdot \mathrm{s}^{-1}$ during the summer (April to June 2012) to $-10 \mu \mathrm{mol} \cdot \mathrm{m}^{-2} \cdot \mathrm{s}^{-1}$ during the winter (October to December 2012), whereas the half-hourly maximum of $\mathrm{H}_{2} \mathrm{O}$ flux varied from 5.5 to $2.5 \mathrm{mmol} \cdot \mathrm{m}^{-2} \cdot \mathrm{s}^{-1}$ during October 2013 and July 2013, respectively. During the study period, the study area was a carbon dioxide sink with an annual net ecosystem productivity $(\mathrm{NEP}=-\mathrm{NEE})$ of $249 \pm 20 \mathrm{~g} \cdot \mathrm{C} \mathrm{m}^{-2}$. year ${ }^{-1}$. The mean annual evapotranspiration (ET) was estimated to be $1.96 \pm 0.33 \mathrm{~mm} \cdot$ day $^{-1}$. The gap-filled NEE was also partitioned into Gross Primary Productivity (GPP) and Ecosystem Respiration $\left(\mathrm{R}_{\mathrm{e}}\right)$. The total GPP and $\mathrm{R}_{\mathrm{e}}$ over the study area for the annual cycle were estimated to be $1271 \mathrm{~g} \mathrm{C} \mathrm{m}^{-2}$. year ${ }^{-1}$ and $1022 \mathrm{~g} \mathrm{C} \mathrm{m}^{-2}$. year ${ }^{-1}$, respectively. The closure of the surface energy balance accounted for of about $78 \%$ of the available energy during the study period. Our findings suggest that the Sundarbans mangroves are currently a substantial carbon sink, indicating that the protection and management of these forests would lead as a strategy towards reduction in carbon dioxide emissions.
\end{abstract}

Keywords: eddy covariance; Sundarban mangroves; carbon dioxide flux; water vapor flux

\section{Introduction}

Carbon dioxide $\left(\mathrm{CO}_{2}\right)$ has been recognized as the most important greenhouse gas responsible for global warming-related climate change. Intergovernmental panel on climate change (IPCC 2013) reported a significant increase of $40 \%$ in the global atmospheric concentration of $\mathrm{CO}_{2}$ from a pre-industrial value of about $278 \mathrm{ppm}$ in 1750 to $390.5 \mathrm{ppm}$ in 2011 . The annual growth rate of $2.0 \pm 0.1 \mathrm{ppm}$ per year in the last decade (i.e., 2002-2011) was observed to be higher than any previous measured decadal rates [1]. The concern about ever-increasing global warming has pushed global interest to understand the potentials of terrestrial ecosystems such as forests to reduce the rise in $\mathrm{CO}_{2}$ levels. Further, the quantification of terrestrial carbon stocks and the understanding of temporal and spatial variation in carbon uptake would help in developing mitigation strategies for increasing atmospheric carbon dioxide.

The terrestrial ecosystems, especially forests, are major $\mathrm{CO}_{2}$ sinks, and they sequester about one-third of the total anthropogenic emissions [2]. Forests also play a crucial role in global carbon dynamics by exchanging trace gases between the atmosphere and the biosphere [3]. Gross primary production (GPP) of the terrestrial ecosystems is the largest global $\mathrm{CO}_{2}$ flux which is estimated to

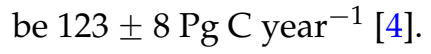


In the tropics, mangroves are the most carbon-rich forests with an average estimate of $1023 \mathrm{MgC} \mathrm{ha}^{-1}$ [5] and high rates of primary production estimated at $218 \pm 72 \mathrm{Tg} \mathrm{C}_{\text {year }}^{-1}$ globally [6]. Thus, due to their tropical distribution $[7,8]$ and rich biogeochemistry $[9,10]$, they are one of the important terrestrial ecosystem at the interface of land and ocean to be understood.

Measurements of $\mathrm{CO}_{2}$ fluxes between forests and atmosphere are important to understand their response to climate change and predict the vegetation feedback to the climate system [4]. Eddy covariance (EC) is the most direct way to measure the exchange rate of $\mathrm{CO}_{2}$ across the soil and vegetation-atmosphere interface at scales of $\sim 1 \mathrm{~km}^{2}$ using micrometeorological theory for different time scales, ranging from hours to years [11-14]. The net ecosystem exchange (NEE), defined as the net $\mathrm{CO}_{2}$ exchange between the ecosystem and the atmosphere, is generally approximated by net ecosystem productivity (NEP) as well in many terrestrial ecosystems $(\mathrm{NEE}=-\mathrm{NEP})$ over short time periods [13]. The EC method is most widely used method to measure $\mathrm{CO}_{2}$ fluxes in over 400 flux research sites in FLUXNET (global flux network) which assimilates information from these sites over a wide range of biomes [15].

Though the importance of mangrove ecosystems in the global carbon budget is significant, limited information exists on the carbon assimilation capacity of mangroves [16]. The oft-reported flux tower in mangroves was established in the coastal Florida Everglades in 2003. Results suggested that everglade mangroves are a carbon sink that had an annual NEP of $1170 \pm 127 \mathrm{~g} \mathrm{C} \mathrm{m}^{-2}$. year ${ }^{-1}$ during 2004 [17].

Sundarbans mangroves are the largest continuous stretch of mangrove forests in the world, covering about $10,000 \mathrm{~km}^{2}$ (i.e., nearly $6 \%-7 \%$ ) of the global mangrove area $\left(15 \times 10^{4} \mathrm{~km}^{2}\right)$ spreading over India and Bangladesh [18]. To understand and estimate the source and sink strengths of these mangroves, few studies have been carried out in selected locations of the Sundarbans deltaic system. The studies using the micrometeorological gradient technique has revealed that the ecosystem was a $\mathrm{CO}_{2}$ sink. Mukhopadhyay et al. had observed the environment of Jambu Island (southwest corner of Indian Sundarbans) to be a sink for $\mathrm{CO}_{2}$ in the pre-monsoon season at a rate of $-56.5 \mathrm{~g} \mathrm{CO}_{2} \mathrm{~m}^{-2}$. day ${ }^{-1}$ [19]. Ganguly et al. have reported a mean net flux of $-48.3 \mathrm{~g} \mathrm{CO}_{2} \mathrm{~m}^{-2}$. day $^{-1}$ at the same Lothian Island and Sajnekhali, and have also estimated a total sink strength of $205 \mathrm{Gg} \cdot \mathrm{day}^{-1}$ for entire reserve forest areas $\left(4264 \mathrm{~km}^{2}\right)$ [20]. During 2011-2012, a series of experiments using micrometeorological measurements were carried out by Chanda et al. in Sundarbans mangroves at different stations viz. Jharkhali, Henry Island and Bonnie Camp to understand the spatial variability of $\mathrm{CO}_{2}$ flux [21]. They have reported that the ecosystem is a sink for $\mathrm{CO}_{2}$ during the daytime with varying fluxes between -33.69 to $-114.91 \mathrm{~g} \mathrm{CO}_{2} \mathrm{~m}^{-2}$. day ${ }^{-1}$.

Though several studies have been attempted to understand the source and sink strengths of the Sundarbans mangroves, there is a huge uncertainty in annual estimates due to variability of $\mathrm{CO}_{2}$ uptake across days over a year. Since the studies so far are mainly for short time periods, the annual $\mathrm{CO}_{2}$ sink strength of this complex mangrove system remains unknown. Recent studies by Pan et al. focus on estimates of carbon sources and sink strengths in various global forests [22]. A huge data gap for the global carbon sequestration estimate in the Indian subcontinent was evident. The present study will also provide the first continuous and accurate measurements of carbon sequestration from Indian mangroves on an annual basis.

This study is an initiative under the Indian Space Research Organisation-Geosphere Biosphere Programme (ISRO-GBP) under the 'National Carbon Project (NCP)'. One of the main objectives of NCP is to establish a network of EC flux towers in different representative forest ecosystems in the Indian subcontinent to understand their $\mathrm{CO}_{2}$ source and sink strengths [23-25]. As part of this, an eddy covariance flux tower was established in mangrove forests in the Sundarbans Biosphere Reserve in April 2012 and has been taking measurements since then. The present EC flux tower stands as one of the few towers established in mangrove ecosystems across the world (FLUXNET). The main objective of the project is to continuously measure and understand vegetation-atmosphere exchanges of $\mathrm{CO}_{2}$ and energy fluxes over Sundarbans (India). The current study is an extension of measuring $\mathrm{CO}_{2}$ and $\mathrm{H}_{2} \mathrm{O}$ fluxes over the flux tower site and presents the first annual results (April 2012-March 2013) of NEE 
measurements over the Sundarbans mangroves, India. The paper also discusses NEE measurements partitioned into GPP and $R_{e}$ (ecosystem respiration, both autotrophic and heterotrophic respiration). Further, we discuss the partitioning of net radiation into sensible and latent heat fluxes during the study period.

\section{Materials and Methods}

\subsection{Study Area}

Sundarbans is the largest single block of tidal halophytic mangrove forest in the world (Figure 1). It lies on the Ganga-Brahmaputra delta at the point where it merges with the Bay of Bengal. The Sundarbans mangrove ecosystem is spread across several islands with $34 \%$ in Indian territory and $66 \%$ in Bangladesh. The total area of the Indian Sundarban region is about $9630 \mathrm{~km}^{2}$, out of which reserve forest area occupies $4264 \mathrm{~km}^{2}$ while the rest of the area is covered by water bodies [20]. The average altitude of the Sundarbans mangroves is $7 \mathrm{~m}$ and it has a wide biodiversity of tree and shrub species. The name Sundarbans is derived from the dominant plant species Heritiera fomes (locally "sundari"). The mangrove system with an unstratified dense canopy is largely undisturbed with no major changes in last few decades (FAO 2005) and it has been a natural habitat for many endangered species including the Bengal tiger. The annual temperature fluctuations in Sundarbans are between $30^{\circ} \mathrm{C}$ and $21^{\circ} \mathrm{C}$, with high temperatures during summer (mid-March to mid-June) and low temperatures during winter (December and January). The Sundarbans region is generally very humid and receives precipitation ranging from $1500 \mathrm{~mm}$ to $1800 \mathrm{~mm}$.
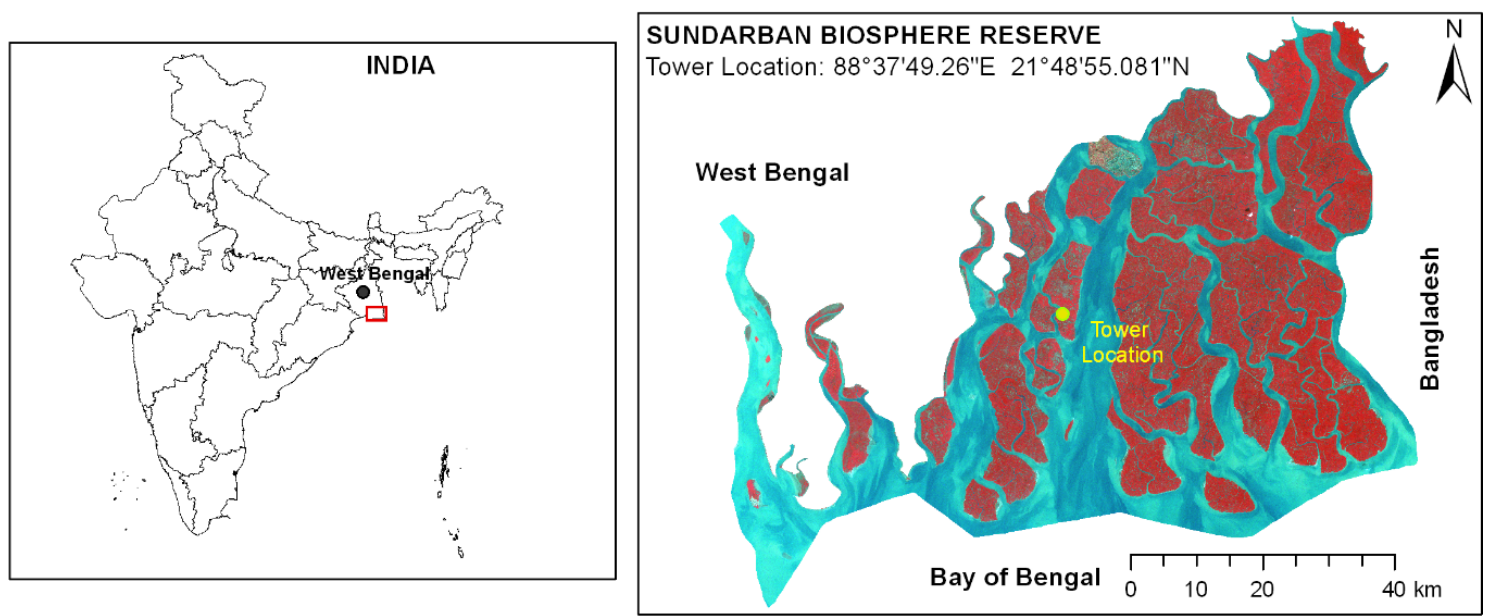

Figure 1. Sundarbans flux tower location on the false color composite (FCC) of IRS AWIFS.

\subsection{Eddy Covariance Flux Tower Setup}

On an uninhabited island of about $11 \mathrm{~km}^{2}$ in Sundarbans, the EC flux tower of $15 \mathrm{~m}$ was established at $21^{\circ} 49^{\prime} \mathrm{N}$ latitude and $88^{\circ} 37^{\prime} \mathrm{E}$ longitude on 1 April 2012 (Figure 1) to measure $\mathrm{CO}_{2}$ and energy fluxes. The tower is surrounded by a continuous mangrove patch with dominant species viz. Avicennia alba, Bruguiera gymnorrhiza, Rhizophora, with a mean canopy height of about $5 \mathrm{~m}$ [23].

A canopy walkway was constructed with cement blocks of $1 \mathrm{~m}$ height across the path to the tower in order to reach the EC tower through the marshy land and water-inundated areas (Figure 2). The tower base is established on a $2 \mathrm{~m} \times 2 \mathrm{~m}$ cement base to prevent it from sinking. The tower of $15 \mathrm{~m}$ is composed of triangular aluminum sections. The well-established guy wires hold the tower straight to perform measurements. All the major tower electronics are housed in a water-proof box at a height of $2 \mathrm{~m}$ above the ground. The tower is powered by three solar panels (120 W each) with rechargeable batteries. 


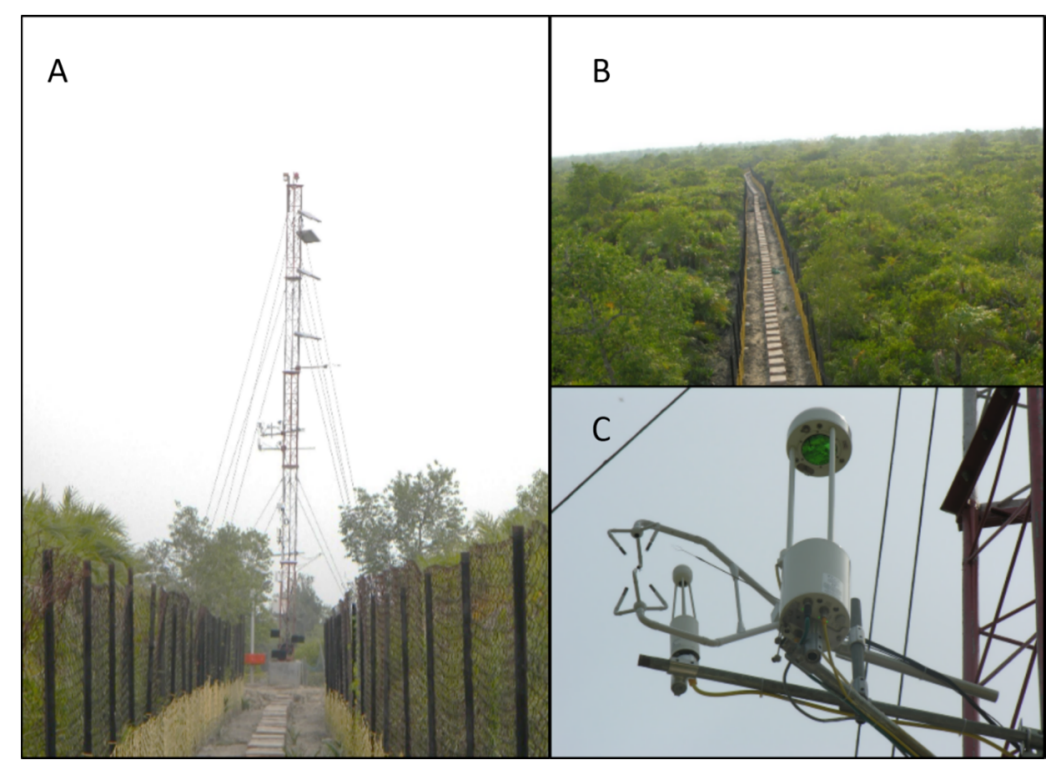

Figure 2. (A) Sundarbans flux tower; (B) Canopy walkway; (C) $\mathrm{CO}_{2}$ and $\mathrm{H}_{2} \mathrm{OIRGA}$ (LI-7500A), Methane IRGA (LI-7700) and 3D sonic anemometer (CSAT-3) mounted on the flux tower.

Micrometeorological and trace gas $\left(\mathrm{CO}_{2}\right)$ measurements were made at a height of $10 \mathrm{~m}$. A three-dimensional (3D) sonic anemometer, CSAT-3 (Campbell Scientific Inc., Logan, UT, USA), was used to measure high frequency wind velocity components (i.e., 3D orthogonal wind components $\mathrm{u}_{\mathrm{x}}, \mathrm{u}_{\mathrm{y}}, \mathrm{u}_{\mathrm{z}}$ ) and sonic temperature $(\mathrm{T})$. Considering the low power and low maintenance requirement at a remote site location such as Sundarbans (uninhabited and marshy land), an open path infrared gas analyzer system (IRGA), LI-7500A (LI-COR, Lincoln, NE, USA) was installed to measure the densities of carbon dioxide and water vapor. The IRGA was slightly angled to allow surface moisture drainage and prevent direct solar radiation from possibly contaminating readings [26]. The raw measurements from the sonic anemometer and IRGA were recorded using an analyzer interface unit, LI-7550 (LI-COR, Lincoln, USA), at a frequency of $10 \mathrm{~Hz}$. The data is collected from 1 April 2012 to 31 March 2013 on a half-hourly basis with short time gaps (about $6 \%$ ) due to low solar power (mostly occurring during rainy season due to continuous rains).

The additional environmental variables were measured above the canopy at $10 \mathrm{~s}$ interval, averaged over $10 \mathrm{~min}$ and logged on to CR3000 (Campbell Scientific Inc. Logan, UT, USA) data logger. These measurements include net radiation (CNR 4; Kipp and Zonen, Delft, Netherlands) and incoming photosynthetic active radiation (PAR, LI-190SB; LICOR, Lincoln, USA) at height of $10 \mathrm{~m}$. Measurements also include air temperature and relative humidity (HMP45C-L; Campbell Scientific Logan, UT, USA), wind speed and wind direction (Wind Monitor 5103; RM Young, Traverse, MI, USA) at heights of $2 \mathrm{~m}$, $4 \mathrm{~m}$ and $8 \mathrm{~m}$. In addition, soil heat flux (HFT-3; Campbell Scientific, Logan, USA) is measured at two levels $(2.5$ and $5 \mathrm{~cm}$ ) and soil temperature (107-B; Campbell Scientific, Logan, UT, USA) at four levels $(5,10,20$ and $40 \mathrm{~cm})$. Precipitation at the study site has been recorded using a tipping bucket TB4-L (Campbell Scientific Inc. Logan, UT, USA).

\section{Flux Calculations and Corrections}

\subsection{Primary Raw Data Processing}

The initial flux processing was done from 1 April 2012 to 31 March 2013 using Eddypro post-processing software (version 5.0, LI-COR, USA). $\mathrm{CO}_{2}$ and energy fluxes are calculated at a standard averaging interval of $30 \mathrm{~min}$ using the fast response measurements from the sonic anemometer (3D wind speed components and sonic temperature) and IRGA (concentrations of $\mathrm{CO}_{2}$ and $\mathrm{H}_{2} \mathrm{O}$ ). 
Every $30 \mathrm{~min}$, raw data is corrected for standard flux corrections for the installed open path system to calculate $\mathrm{CO}_{2}$ flux $(\mathrm{Fc})$, termed as the mean covariance between deviations in instantaneous vertical wind speed $\left(w^{\prime}\right)$ and density of $\mathrm{CO}_{2}$ in air $\left(c^{\prime}\right)[11]$.

$$
F_{c}=\overline{w^{\prime} c^{\prime}}
$$

The standard flux corrections include the removal of bad data in fast response measurements by de-spiking, de-trending and correcting for time delays [27]. The tilt corrections for sonic measurements are made by axis rotation such that mean vertical wind $(w)$ is null [28]. Frequency response corrections are applied to compensate for flux losses at different frequencies (eddy sizes) [29,30]. The density fluctuations of $\mathrm{CO}_{2}$ and $\mathrm{H}_{2} \mathrm{O}$ due to temperature (thermal expansion) and water vapor (dilution) were compensated by Webb-Pearman-Leuing (WPL) Corrections [31]. The EC system measures the fastest and smallest eddies accurately when the terrain is flat and homogenous.

\subsection{Secondary Data Processing}

The half-hourly computed flux data after standard corrections have spikes due to unrealistic meteorological measurements. These erroneous values affect the annual estimates and thus it is important to further correct the computed fluxes by removal of spurious data and to fill the gaps with more reasonable estimates. Further, the data has gaps due to shut-down of the tower because of the limitations of the solar power supply. Over annual measurements from April 2012 to March 2013, we had an actual data gap of about $11 \%$ of the total data due to low power and instrumental errors.

The secondary data processing includes the removal of $\mathrm{CO}_{2}$ spikes, Latent Heat (LE) and Sensible Heat $(\mathrm{H})$ spikes and corrections for nighttime flux based on statistical analysis. The corrected data is then gap-filled and partitioned into gross primary productivity (GPP) and ecosystem respiration (Re). The secondary data processing methodology used is similar to the proposed corrections by Thomas et al. [32].

\subsection{1. $\mathrm{CO}_{2}$ Flux Spike Removal}

The computed flux data may have unrealistic spikes though the raw data are filtered using standard corrections. It is assumed that the extreme spikes are due to non-localized advection events or other non-stationary phenomena and not because of the natural phenomena [32].

The spikes were removed using statistical bounds on the data using a two-stage approach. Firstly, the data was grouped into positive and negative fluxes. Then half-hourly positive flux values which are greater than the respective month average plus two times the standard deviation $(x>x+2 \times \sigma)$ are removed. The opposite was used for removal of absurd data in the negative fluxes $(x<x-2 \times \sigma)$. In the second stage, positive (or negative) flux values greater (or lesser) than the respective monthly diurnal average plus (or minus) two times the standard deviation were removed. After the first stage about $13 \%$ of data was removed and an additional $2 \%$ was removed after the second stage.

\subsubsection{LE and H Flux Spike Removal}

The spikes in the energy fluxes are removed simply by using thresholds. Erroneous values of latent heat flux and sensible heat fluxes are removed from the dataset using similar thresholding as that described in Section 3.2.1. These may have resulted from strong advection or sensor interference which affects the reliability of associated $\mathrm{CO}_{2}$ and energy fluxes, which were subsequently removed. Additional data of about $1 \%$ was removed after thresholding.

\subsubsection{Removal of Negative Nighttime $\mathrm{CO}_{2}$ Fluxes}

This includes the removal of negative nighttime fluxes in the primary processed flux data post-spike removal. Identification of nighttime fluxes was made using PAR (Photosynthetic Active Radiation) less than $20 \mu \mathrm{mol} \cdot \mathrm{m}^{-2} \cdot \mathrm{s}^{-1}$. During the night, there is no chance of net $\mathrm{CO}_{2}$ assimilation 
by the forest, thus these fluxes are related to the advection events which are likely at this site under stable nighttime conditions. Removal of such data caused a data gap of around $23 \%$. There is no universal method to account for advection [33] and our method is in agreement with the several authors recording such errors using open path systems [26,32,34].

\subsubsection{Friction Velocity Correction}

Though the eddy covariance method is perhaps the best and most direct method for measuring mass and energy exchanges for terrestrial ecosystems, during the night it becomes complicated and uncertain because of the low turbulence and relatively stable air stratification. The standard method to process nighttime $\mathrm{CO}_{2}$ flux data is to primarily assess the quality of the nighttime flux data using the friction velocity threshold, then to establish statistical models using reliable nighttime $\mathrm{CO}_{2}$ flux data with meteorological data. Finally, we correct the incorrect data using the established model [35].

Since low friction velocity $\left(\mathrm{u}^{*}\right)$ corresponds to calm nights, the $\mathrm{u}^{*}$ threshold is used to identify the low turbulent flux data and the reliable flux data as described by Reichstein et al. [36]. This method is the statistically based, site-independent determination of the lower $\mathrm{u}^{*}$ threshold. The $\mathrm{CO}_{2}$ flux data is divided into six temperature classes with equal sample size. Each temperature class is subdivided into $20 \mathrm{u}^{*}$ classes. The $\mathrm{u}^{*}$ threshold for each temperature class was defined as the $\mathrm{u}^{*}$ class where the nighttime flux reached more than $95 \%$ of the average flux within the higher $\mathrm{u}^{*}$ classes. In order to account for seasonal variation in vegetation, the final $\mathrm{u}^{*}$ threshold was calculated in three-month subsets as the median of the six temperature classes. The obtained $\mathrm{u}^{*}$ thresholds for three-month subset data were $0.1,0.13,0.12$ and 0.08 , respectively. If the $\mathrm{u}^{*}$ threshold was unable to be determined, a default value of $0.2 \mathrm{~m} \cdot \mathrm{s}^{-1}$ was used. The low turbulent flux data were subsequently removed, which amounts to $12 \%$ of the total data.

\subsubsection{Gap-Filling and Uncertainty Analysis}

In order to form a continuous dataset for annual carbon budgeting, the deleted data is replaced using gap-filled values. Several gap-filling methods have been developed based on interpolation, probabilistic filling, look-up tables, non-linear regression and artificial neural networks [37]. In the present study, a total of $35 \%$ of data is deleted after spike removal of energy fluxes and $\mathrm{CO}_{2}$ fluxes (including the deletion of negative nighttime values and low turbulence fluxes). To form a continuous dataset, we used standard procedures such as the marginal data sampling method (MDS) and mean diurnal variation (MDV) to substitute for the deleted values [36,38]. Both MDS and MDV methods have proven to be unbiased approaches for gap-filling in comparison with other techniques [37].

The error and bias in fluxes caused by gap-filling methods (MDS and MDV) were estimated using the random creation of artificial gaps and then refilling these gaps using the valid data periods [37]. During the study period, around 150 half-hourly fluxes were randomly removed to create an artificial gap and then filled with values to compare with the original values. The root mean square error (RMSE) and the bias error (BE) were determined using the flux estimations from 100 simulations. The computed RMSE of $\mathrm{CO}_{2}$ flux $1.81 \pm 0.24 \mu \mathrm{mol} \cdot \mathrm{m}^{-2} \cdot \mathrm{s}^{-1}$ was in the reported range of gap-filling errors in six forested types in Europe [37]. The low BE $\left(0.13 \pm 0.1 \mu \mathrm{mol} \cdot \mathrm{m}^{-2} \cdot \mathrm{s}^{-1}\right)$ value suggests the minimal bias in the annual NEP estimates. Similarly, the computed RMSE of $\mathrm{H}_{2} \mathrm{O}$ flux was also found to be $0.73 \pm 0.12 \mu \mathrm{mol} \cdot \mathrm{m}^{-2} \cdot \mathrm{s}^{-1}$.

\subsection{Flux Partitioning}

The $\mathrm{CO}_{2}$ flux data after $\mathrm{u}^{*}$ threshold correction were partitioned into gross primary productivity (GPP) and ecosystem respiration. The reliable nighttime data (i.e., after removal of low turbulent flux data) is regressed with air temperature using the Lloyd-Taylor regression model [39]. The air temperature is used as a proxy for ecosystem respiration to estimate daily respiration rates over a 14-day period. GPP is subsequently calculated as the difference between NEE and respiration. During nights, GPP cannot be negative or non-zero; such values are treated as errors and are forced to zero. During 
such cases, the ecosystem respiration was estimated to be the same as NEE due to the uncertainty in the regression model. For the secondary corrections, gap-filling and flux partitioning procedures, we used the REddyproc package [40] in an open source R environment along with MATLAB scripts to form the continuous datasets. REddyproc implements the same standardized methods as those described by Reichstein et al. [36] and is currently employed by CarboEurope.

\section{Results and Discussions}

\subsection{Meteorological Data}

Figure 3 shows the annual daily means of temperature, relative humidity, soil temperature, and solar radiation. The climate of the study area is hot and humid during most of the year. The maximum temperature of $32{ }^{\circ} \mathrm{C}$ occurred during June 2012 and the minimum temperature of $13{ }^{\circ} \mathrm{C}$ occurred during December 2012. The relative humidity was recorded to be greater than $70 \%$ for most of the year (Figure 3). Lower humidity values (nearly 50\%) were recorded during winters (December 2012 to February 2013). Annual variations of temperature imply that May and June were hotter months with an average daily temperature of $30^{\circ} \mathrm{C}$ whereas December and January were the colder months with an average daily temperature of $18^{\circ} \mathrm{C}$. The total precipitation at the study site was recorded to be $1267 \mathrm{~mm}$ during the study period, with nearly $80 \%$ of the total during monsoons (July to September). Figure 4 shows the monthly precipitation at the tower site.

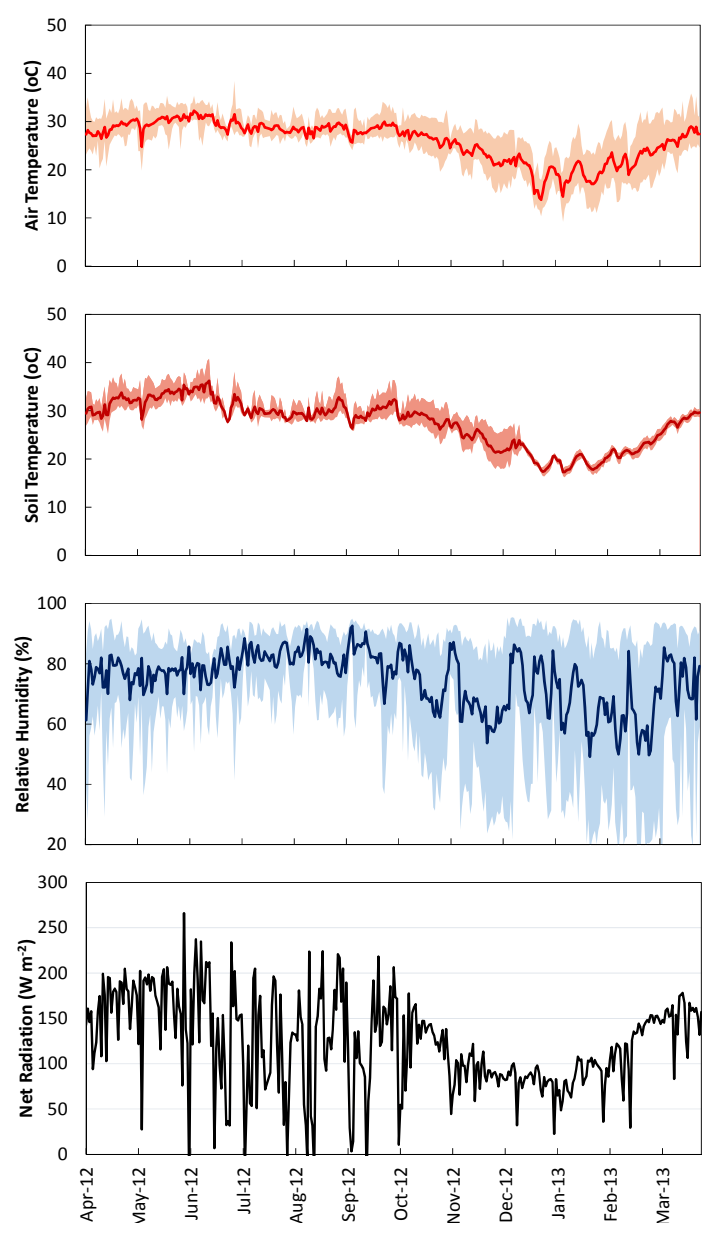

Figure 3. Daily averages of meteorological variables over Sundarbans from April 2012 to March 2013. Bold lines represent the averages and the shaded area represents the min-max range. For net radiation, only average value is depicted. 


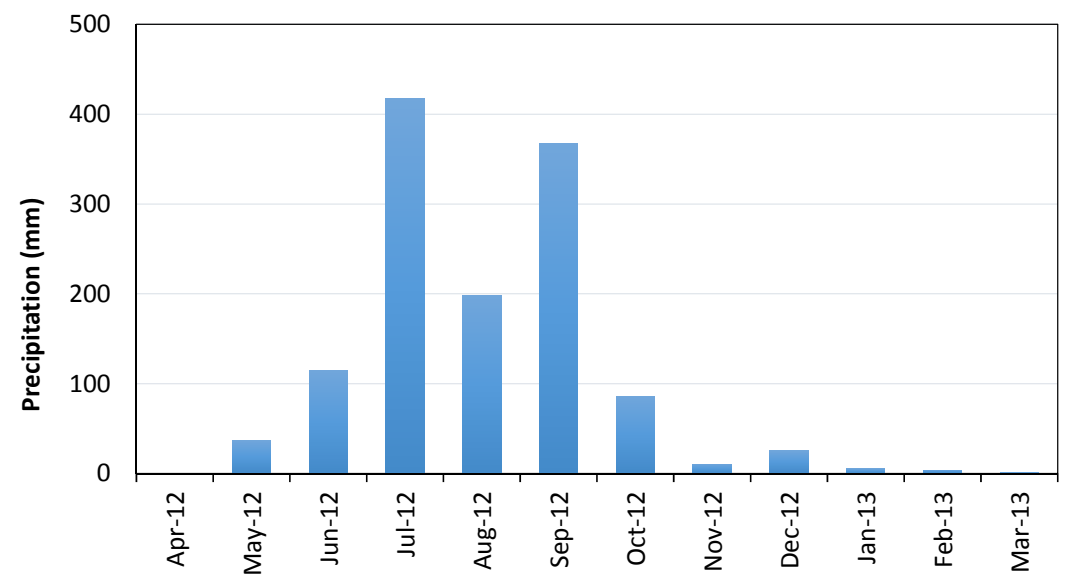

Figure 4. Total monthly precipitation during April 2012 to March 2013.

\subsection{Variations in $\mathrm{CO}_{2}$ Flux and $\mathrm{H}_{2} \mathrm{O}$ Flux}

The footprint (or fetch) which is attributed to $90 \%$ of the total turbulent flux computations was estimated using the Kljun et al., model [41]. The average footprint during the day was estimated to be about $160 \mathrm{~m}$ with a standard deviation of $22 \mathrm{~m}$ during the study period (Figure 5). Figure 6 depicts the variations of monthly diurnal averaged carbon dioxide flux over a year (April 2012 to March 2013). Even though mangroves are less prone to phenological changes, there is significant seasonal variation in $\mathrm{CO}_{2}$ flux when observed annually. Variations in ecosystem respiration during nights (positive $\mathrm{CO}_{2}$ flux) were minimal with values ranging between 2 to $4 \mu \mathrm{mol} \cdot \mathrm{m}^{-2} \cdot \mathrm{s}^{-1}$ throughout the year, whereas $\mathrm{CO}_{2}$ flux due to photosynthesis during the day (negative $\mathrm{CO}_{2}$ flux) peaked at $-6 \mu \mathrm{mol} \cdot \mathrm{m}^{-2} \cdot \mathrm{s}^{-1}$ during the summer season (April 2012 to June 2012) and decreased to $-10 \mu \mathrm{mol} \cdot \mathrm{m}^{-2} \cdot \mathrm{s}^{-1}$ during the winter period (October 2012 to December 2012). The half-hourly maximum daytime NEE of $-11.8 \mu \mathrm{mol} \cdot \mathrm{m}^{-2} \cdot \mathrm{s}^{-1}$ was observed during October 2012. The diurnal and seasonal variation of $\mathrm{CO}_{2}$ fluxes over a year are depicted in Figure 7 , which shows the gap-filled NEE (in $\mu \mathrm{mol} \cdot \mathrm{m}^{-2} \cdot \mathrm{s}^{-1}$ ) with respect to time of day and month.

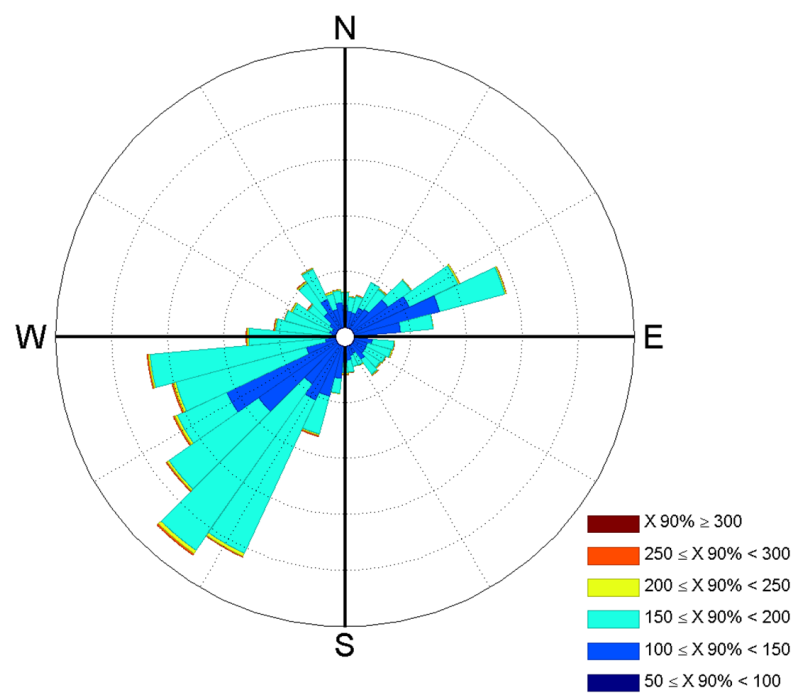

Figure 5. Sundarbans flux tower foot print of $90 \%$ of the flux contribution (represented by X $90 \%$ ) over the study period ranged from $90 \mathrm{~m}$ to $300 \mathrm{~m}$. 


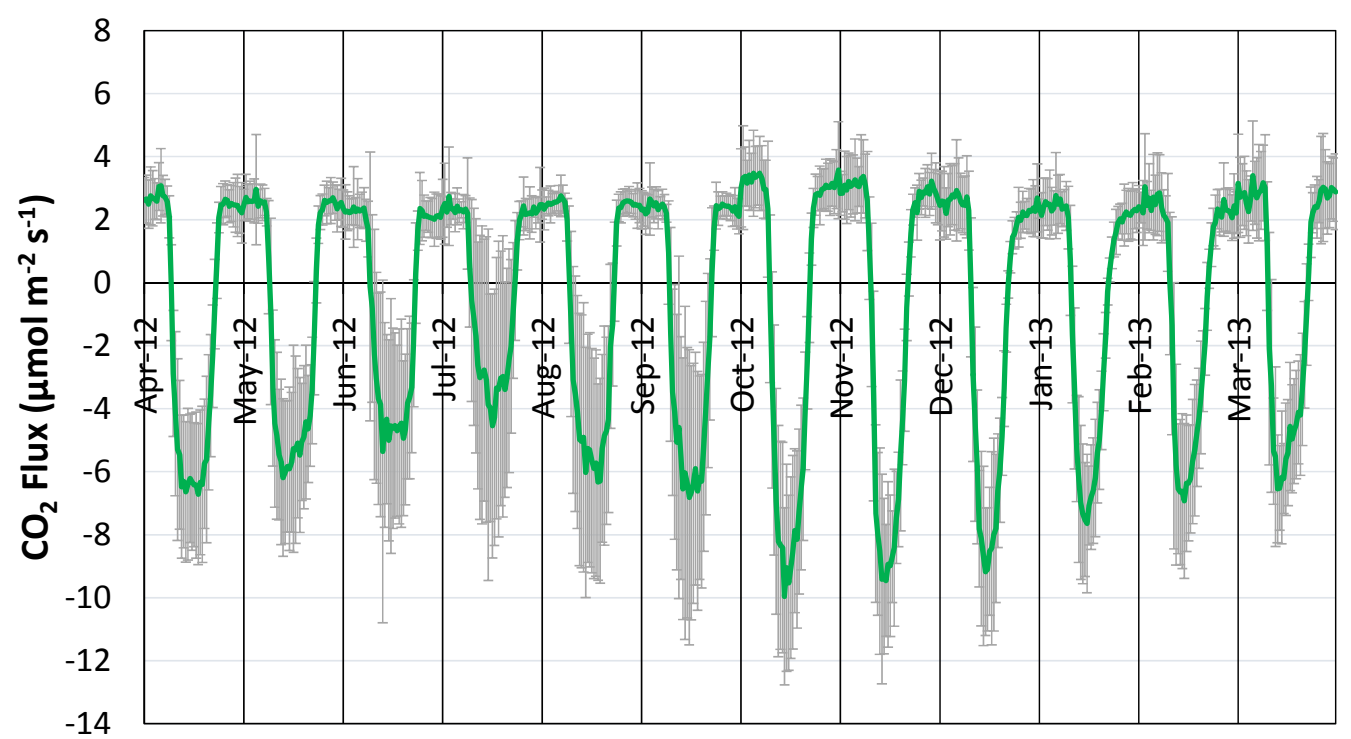

Figure 6. Monthly mean diurnal variation of half-hourly $\mathrm{CO}_{2}$ flux during April 2012 to March 2013. The error bars show one standard deviation of the diurnal average fluxes during respective months.

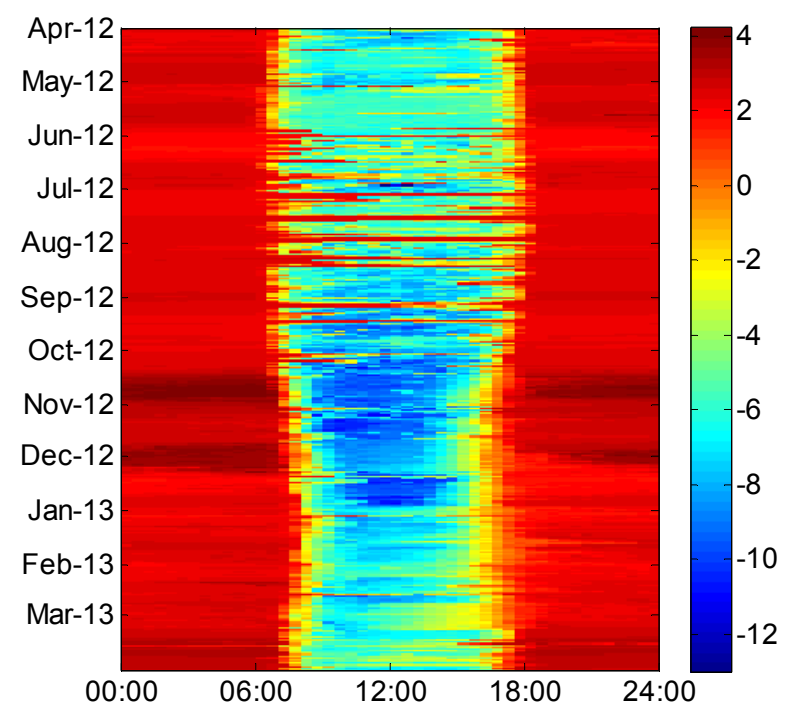

Figure 7. Gap-filled net ecosystem exchange (NEE) fingerprint of Sundarbans mangroves showing time of the day ( $x$-axis) and month-wise ( $y$-axis) $\mathrm{CO}_{2}$ fluxes in $\mu \mathrm{mol} \cdot \mathrm{m}^{-2} \cdot \mathrm{s}^{-1}$ during the study period.

Water vapor fluxes (or evapotranspiration (ET) rates), defined as the sum of evaporation and transpiration over an ecosystem, varied between a maximum of $5.5 \mathrm{mmol} \cdot \mathrm{m}^{-2} \cdot \mathrm{s}^{-1}$ in October 2012 to a minimum of $2.5 \mathrm{mmol} \cdot \mathrm{m}^{-2} \cdot \mathrm{s}^{-1}$ in July 2013 (Figure 8). The majority of $\mathrm{H}_{2} \mathrm{O}$ fluxes were found to be positive throughout the year with a steady increase during the daytime (photosynthesis and high ET rates), peaking during mid-day (1200 to $1300 \mathrm{~h}$ ) and decreasing to the lowest during the night (no photosynthesis, lowest ET rates). The mean annual ET during the study period was estimated to be $1.96 \pm 0.33 \mathrm{~mm} \cdot$ day $^{-1}$.

The maximum daytime NEE obtained from the Florida Everglades mangroves is about -20 to $-25 \mu \mathrm{mol} \cdot \mathrm{m}^{-2} \cdot \mathrm{s}^{-1}$ [17]. The NEE values obtained are only one-third of the NEE observed at the Florida Everglades mangroves. The tree heights in the mangroves of the Florida Everglades are 15-20 m [17] which, compared to the mean height of $5 \mathrm{~m}$ in the mangroves of Sundarbans, is the possible explanation of the huge variation in NEE. 


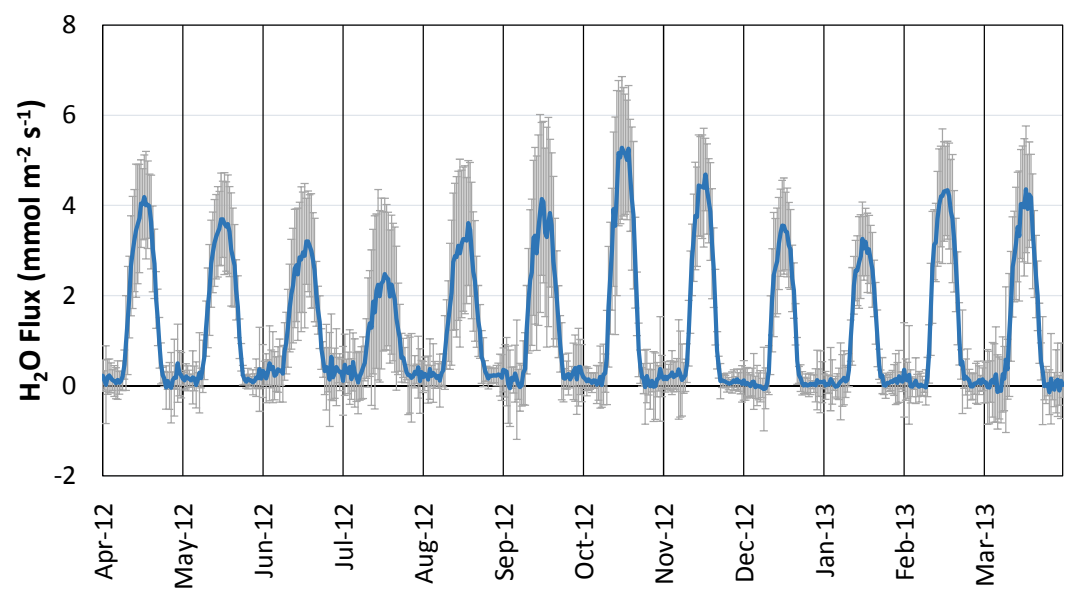

Figure 8. Monthly mean diurnal variations of half-hourly $\mathrm{H}_{2} \mathrm{O}$ flux during April 2012 to March 2013.

The error bars show one standard deviation of the diurnal average fluxes during the respective months.

\subsection{Heat Fluxes and Energy Balance}

The maximum half-hourly measured net solar radiation $\left(R_{n}\right)$ was nearly $700 \mathrm{~W} \cdot \mathrm{m}^{-2}$ during the summer season (April 2012 and March 2013) and $500 \mathrm{~W} \cdot \mathrm{m}^{-2}$ during the winters (November 2012 to January 2013). The partitioning of the net available energy into sensible heat flux $(\mathrm{H})$ and latent heat flux (LE) was almost the same throughout the year. During the study period from April 2012 to March 2013, both H and LE showed a linear relationship with net radiation with values peaking during midday.

The monthly diurnal average values of sensible heat flux (maximum of $240 \mathrm{~W} \cdot \mathrm{m}^{-2}$ during April 2012) and latent heat flux (maximum of $240 \mathrm{~W} \cdot \mathrm{m}^{-2}$ during October 2012) depicts that the net radiation was equally divided into both energy fluxes for most months of the year (Figure 9). During July 2012 to November 2012, energy partitioning into latent heat flux was slightly higher than the sensible heat flux. This is largely due to the availability of water due to rain events, which triggered evapotranspiration at the study site.

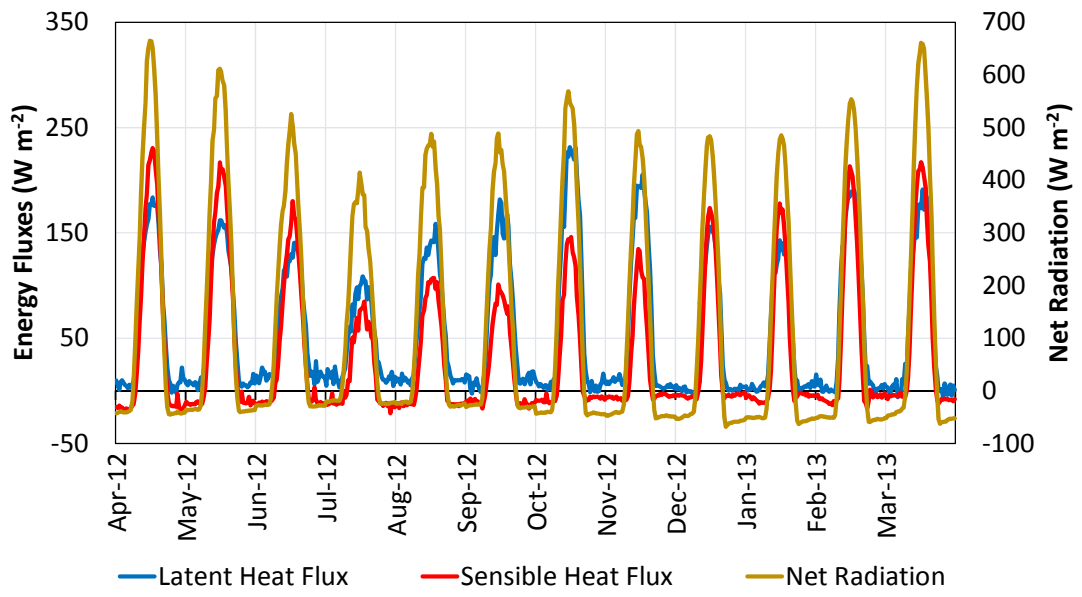

Figure 9. Annual variation of monthly mean diurnal variation of sensible heat and latent heat fluxes.

Closure of the surface energy balance provides insight into the performance of the eddy covariance measurement system [11,42]. For each half-hour period, the total net radiation $\left(R_{n}\right)$ should be approximately equal to the sum of the energy distributed between the LE, $\mathrm{H}$, and soil heat flux 
(G) and canopy heat storage (S). Since the canopy heat storage (S) is expected to be small in short canopies with minimal biomass [42], the surface energy balance at the surface can be expressed as:

$$
R_{n}-G=H+L E
$$

Figure 10 shows the energy closure of the Sundarbans study area during the day from April 2012 to March 2013 with measured half-hourly flux values. Figure 10 also depicts that the slope of the regression $(m=0.78)$ was less than one and the intercept $(c=18.7)$ was slightly greater than zero with an $R^{2}=0.74$. The surface energy balance of about $78 \%$ of the available energy is accounted for by the 30-min fluxes in the present mangrove ecosystem. Although the energy balance closure is not perfect, it is the typical range reported at other flux sites. Wilson et al., 2002, used 22 FLUXNET sites of different vegetation heights and compositions and reported the ranges of slope, intercept and $R^{2}$ to be in between 0.53 and $0.99,-32.9$ and $36.9 \mathrm{~W} \cdot \mathrm{m}^{-2}$, and 0.64 and 0.36 , respectively. Other long-term eddy covariance studies also indicate that the measurements do not show a closure of surface energy balance, although this discrepancy is not well understood [42-44]. It is also considered that the imbalance may be due to the sensor accuracy, data processing and under-estimations of the advections due to homogenous terrain.

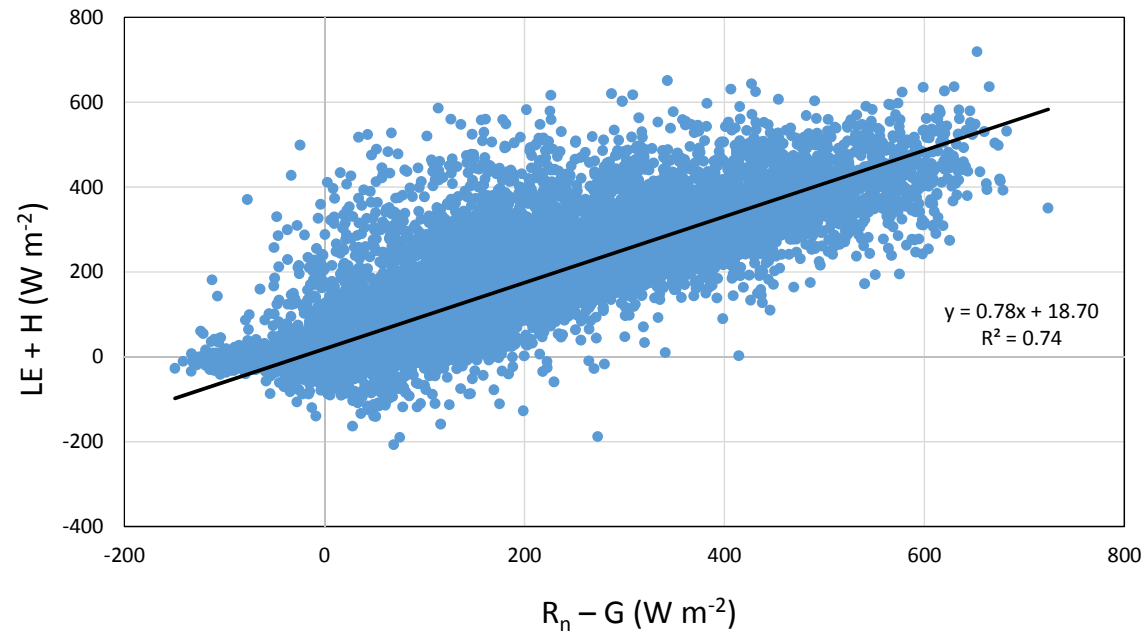

Figure 10. Surface energy closure in daytime in the Sundarbans mangroves during April 2012 to March 2013 with half-hourly fluxes. Soil heat flux includes energy storage between the surface and the $5 \mathrm{~cm}$ soil.

\subsection{Net Carbon Sequestered}

Figure 11 shows the daily 30-min average of the NEP partitioned into GPP and respiration (Re). The bold lines represent the weekly average for the partitioned fluxes. Positive fluxes of NEP and GPP represent net sequestration (sink) by the forest ecosystem whereas negative values indicate a net loss (source) of $\mathrm{CO}_{2}$ to the atmosphere. Respiration represents the net release of $\mathrm{CO}_{2}$ from the ecosystem to the atmosphere.

During the study period, daily GPP estimates ranged from 3 to $5.5 \mathrm{~g} \mathrm{C} \mathrm{m}^{-2}$. day ${ }^{-1}$ during October and November 2012, and between 2.5 to $4 \mathrm{~g} \mathrm{C} \mathrm{m}^{-2}$. day ${ }^{-1}$ during January and February 2013. Greater fluctuations ( 1 to $4.5 \mathrm{~g} \mathrm{C} \mathrm{m}^{-2}$. day ${ }^{-1}$ ) were recorded during monsoon periods (July and August 2012), which may be attributed to less availability of photosynthetic radiation during cloudy/rainy days. The annual variation of the day-wise ecosystem respiration was also similar to GPP, with maximum values of around $5.5 \mathrm{~g} \mathrm{C} \mathrm{m}^{-2}$. day ${ }^{-1}$ during October and November 2012 and minimum values of $2 \mathrm{~g} \mathrm{C} \mathrm{m}^{-2} \cdot \mathrm{d}^{-1}$ during January and February 2013. Figure 11 also indicates that the daily NEPs are positive throughout the majority of days during the study period, suggesting that the ecosystem 
is a sink for $\mathrm{CO}_{2}$. During September to December 2012, the values of NEP were measured to be nearly $2.5 \mathrm{~g} \mathrm{C} \mathrm{m}^{-2}$. day ${ }^{-1}$ and they decreased to around $0.5 \mathrm{~g} \mathrm{C} \mathrm{m}^{-2}$. day ${ }^{-1}$ during January to March 2013.
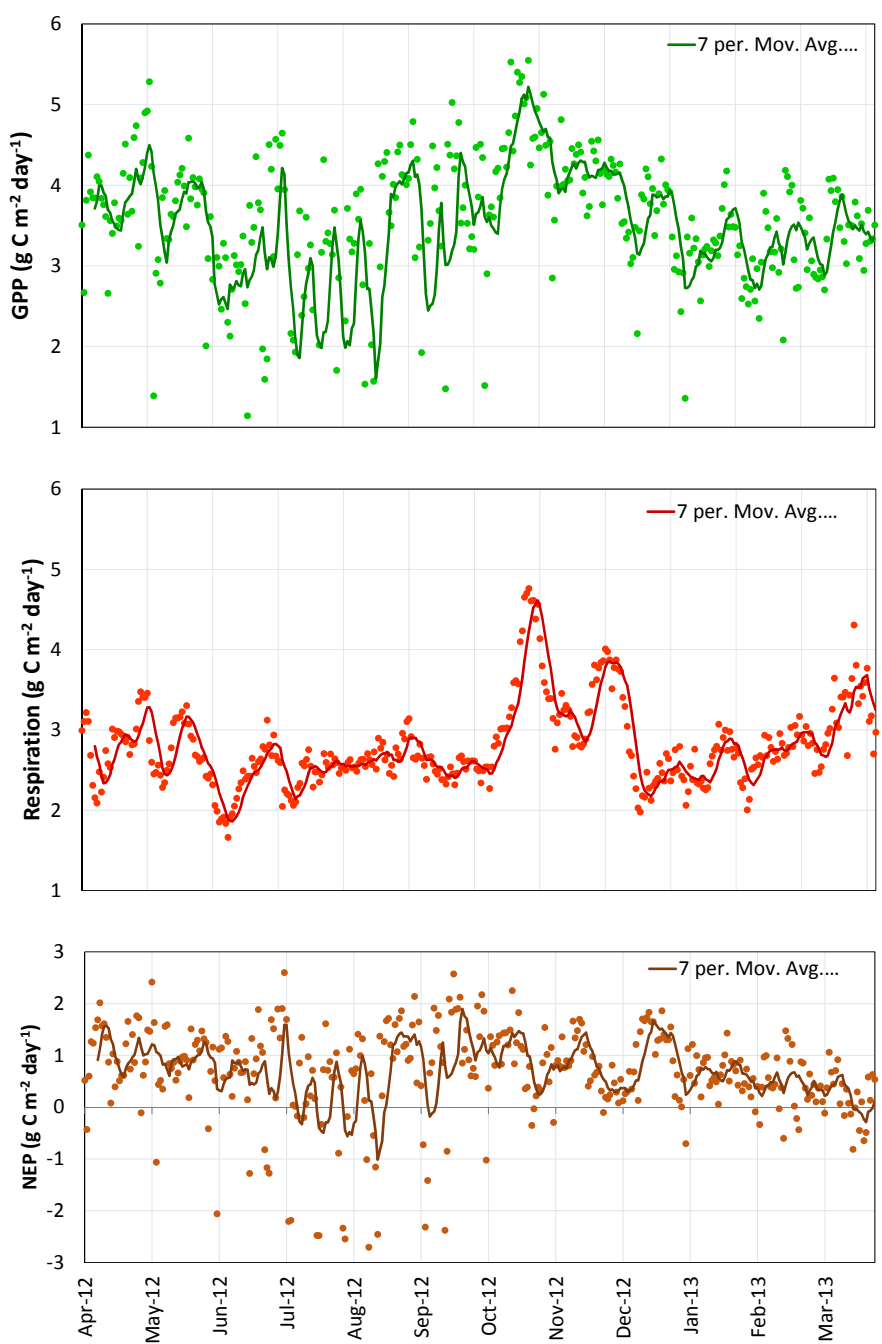

Figure 11. Daily average of partitioned flux into gross primary productivity (GPP), respiration (Re) and net ecosystem productivity (NEP) over the study period. Bold lines represent seven-day running mean.

Over one year (April 2012 to March 2013), the estimated NEP was $249 \pm 20 \mathrm{~g} \mathrm{C} \mathrm{m}^{-2}$. year ${ }^{-1}$. The estimated GPP and $\mathrm{R}_{\mathrm{e}}$ were $1271 \mathrm{~g} \mathrm{C} \mathrm{m}^{-2}$. year ${ }^{-1}$ and $1022 \mathrm{~g} \mathrm{C} \mathrm{m}^{-2}$. year ${ }^{-1}$, respectively (Table 1 ). The estimated NEP values ( $249 \mathrm{~g} \mathrm{C} \mathrm{m}^{-2}$. year ${ }^{-1}$ ) during April 2012 to March 2013 fall in the reported range for terrestrial ecosystems [45-47]. In comparison with the mangroves of the Florida Everglades $\left(\mathrm{NEP}=1170 \pm 145 \mathrm{~g} \mathrm{C} \mathrm{m}^{-2}\right.$. year ${ }^{-1}$ ), the estimated NEP of Sundarbans is quite low and is attributed to the fact that the Everglades mangroves are dense with trees of greater heights, have a high leaf litter rate and also have a greater wood production [17]. Also, the species composition which contributes to biomass and, in turn, NEP is different in the wet evergreen system of Sundarbans (predominant species viz. Avicennia alba, Bruguiera gymnorrhiza and Rhizophora) in comparison with the mangroves of the Everglades (predominant species viz. Rhizophora mangle, Avicennia germinans and Laguncularia racemosa). The presence of significantly less biomass $\left(10-50 \mathrm{t} \cdot \mathrm{ha}^{-1}\right)$ in the Sundarbans mangrove forest [48] in comparison with the high biomass of around 150-200 $\mathrm{t} \cdot \mathrm{ha}^{-1}$ in the Everglades mangroves [49] explains the huge difference in the NEP. 
Table 1. Summary table of annual estimates of $\mathrm{CO}_{2}$ fluxes and evapotranspiration rates (ET) over the study period.

\begin{tabular}{|c|c|c|}
\hline & Estimated Values & $\%$ Gap-Filled \\
\hline Bias Error $\left(\mathrm{CO}_{2}\right.$ flux $)$ & $0.13 \pm 0.1 \mu \mathrm{mol} \cdot \mathrm{m}^{-2} \cdot \mathrm{s}^{-1}$ & \\
\hline $\operatorname{RMSE}\left(\mathrm{CO}_{2}\right.$ flux $)$ & $1.81 \pm 0.24 \mu \mathrm{mol} \cdot \mathrm{m}^{-2} \cdot \mathrm{s}^{-1}$ & \\
\hline Net Ecosystem Productivity (NEP) & $249 \pm 20 \mathrm{~g} \mathrm{C} \mathrm{m}^{-2} \cdot$ year $^{-1}$ & $35 \%$ \\
\hline Gross Primary Productivity (GPP) & $1271 \mathrm{~g} \mathrm{C} \mathrm{m}^{-2} \cdot$ year $^{-1}$ & $35 \%$ \\
\hline Ecosystem Respiration (Reco) & $1022 \mathrm{~g} \mathrm{C} \mathrm{m}^{-2} \cdot$ year $^{-1}$ & $35 \%$ \\
\hline RMSE $\left(\mathrm{H}_{2} \mathrm{O}\right.$ flux $)$ & $0.73 \pm 0.12 \mu \mathrm{mol} \cdot \mathrm{m}^{-2} \cdot \mathrm{s}^{-1}$ & \\
\hline Evapotranspiration (ET) & $715 \pm 120 \mathrm{~mm} \cdot$ year $^{-1}$ & $20 \%$ \\
\hline
\end{tabular}

The measured respiration rates ( 2 to $4 \mu \mathrm{mol} \cdot \mathrm{m}^{-2} \cdot \mathrm{s}^{-1}$ ) were low throughout the year in comparison with other forest types. It was reported by the measurements across terrestrial AmeriFlux and EuroFlux sites that the respiration rates range from $3.72 \pm 2.20$ to $5.92 \pm 4.40 \mu \mathrm{mol} \cdot \mathrm{m}^{-2} \cdot \mathrm{s}^{-1}$ at different soil temperatures of $15^{\circ} \mathrm{C}$ and $20^{\circ} \mathrm{C}$, respectively [38]. In the study area, though high soil temperatures $\left(20^{\circ} \mathrm{C}\right.$ to $\left.30^{\circ} \mathrm{C}\right)$ were recorded, the observed respiration rates were less than half of the globally reported values. Due to the consistent high water level around the tower site, the soils are generally anoxic and would have contributed to low respiration rates.

\subsection{NEE and Photosynthetic Active Radiation (PAR)}

Since the photosynthetic activity is limited to the availability of photons rather than other limiting factors, daily variations in GPP were also correlated with daily averaged photosynthetic active radiation (PAR). GPP shows a positive non-linear relation with daily averaged PAR, indicating that GPP increases with PAR up to a certain value and saturates further (Figure 12).

Though Sundarbans mangroves exhibit less phenological changes, a relative increase in NEE sequestration was observed during September 2012 to December 2012 compared to other months (Figure 6). Accordingly, relationships of monthly diurnal averaged NEE with monthly diurnal averaged PAR were analyzed in two phases. During September 2012 to December 2012, NEE increased incrementally with PAR until reaching $900 \mu \mathrm{mol} \cdot \mathrm{m}^{-2} \cdot \mathrm{s}^{-1}$, thereafter leveling off at $-8 \mu \mathrm{mol} \cdot \mathrm{m}^{-2} \cdot \mathrm{s}^{-1}$ incrementally with PAR (Figure 13). During the remaining period, NEE showed a similar trend in response with PAR, but saturated at lower levels of sequestration around $5.5 \mu \mathrm{mol} \cdot \mathrm{m}^{-2} \cdot \mathrm{s}^{-1}$ (Figure 13).

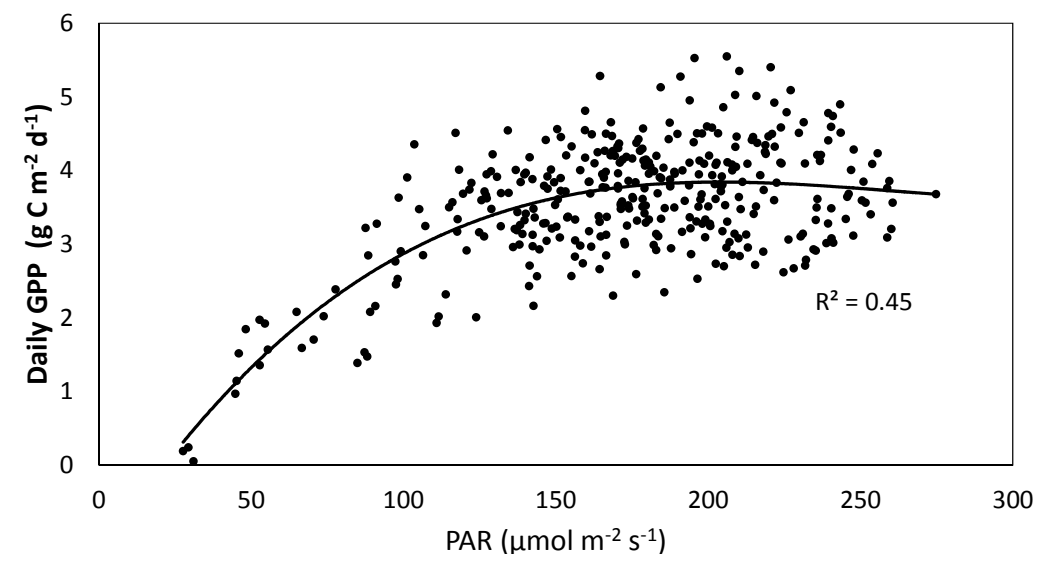

Figure 12. Relationship between daily GPP and daily average photosynthetic absorbed radiation (PAR) during daytime. 


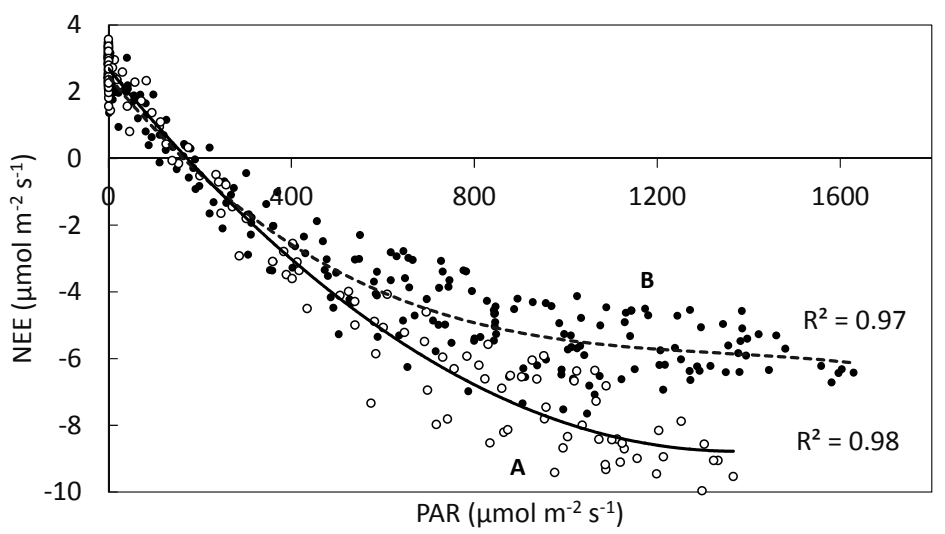

Figure 13. Least square fits of NEE vs. PAR for (A) September 2012 to December 2012 (hollow circles);

(B) Rest of the study period (April-August 2012 and January-March 2013) (filled circles).

Apparent quantum yield $(\alpha)$, described as the number of molecules of $\mathrm{CO}_{2}$ fixation per unit of photons irradiated on the leaf, plays an important role in understanding the tree photosynthetic response, and estimating " $\alpha$ " would provide useful information for ecosystem models over larger areas [50]. Apparent quantum yield is often calculated by fitting a rectangular hyperbolic function between NEE and PAR, where there is a near-linear response during low light conditions and saturation to maximum productivity at higher light conditions. The ecosystem photosynthetic parameters in the present study are estimated using the Michaelis-Menten equation as given below and as described by Ruimy et al. [51].

$$
N E E=\frac{\alpha * P A R * P_{\max }}{\alpha * P A R+P_{\max }}-R_{e}
$$

where $\alpha\left(\mu \mathrm{mol} \mathrm{CO}_{2} \mu \mathrm{mol} \cdot\right.$ photon $\left.^{-1}\right)$ is the ecosystem apparent quantum yield, $P_{\max }$ $\left(\mu \mathrm{mol} \mathrm{CO} \mathrm{C}^{-2} \cdot \mathrm{s}^{-1}\right)$ is the maximum photosynthetic capacity and $\operatorname{Re}\left(\mu \mathrm{mol} \mathrm{CO} \mathrm{CO}^{-2} \cdot \mathrm{s}^{-1}\right)$ is the daytime ecosystem respiration. The month-wise estimated coefficients are shown in Table 2. Estimated quantum yield varied from a minimum of $0.0205 \pm 0.0019$ ( $95 \%$ confidence) in May 2012 to a maximum of $0.0398 \pm 0.0038$ in September 2012. Higher quantum yield in September 2012 is observed to be in accordance with favorable growing conditions at the study site, and lower quantum yield during May 2012 could be mainly attributed to high temperatures recorded at the study site.

Table 2. Monthly estimates of ecosystem photosynthesis parameters with standard error (95\% confidence).

\begin{tabular}{|c|c|c|c|c|}
\hline Month & $P_{\max }\left(\mu \mathrm{mol} \mathrm{CO} \mathrm{Cm}^{-2} \cdot \mathrm{s}^{-1}\right)$ & $\alpha\left(\mu \mathrm{mol} \mathrm{CO} \mathrm{CO}_{2} \mu \mathrm{mol} \cdot\right.$ photon $\left.^{-1}\right)$ & $R_{e}\left(\mu \mathrm{mol} \mathrm{CO} \mathrm{m}^{-2} \cdot \mathrm{s}^{-1}\right)$ & $R^{2}$ \\
\hline 12 April & $13.94 \pm 0.45$ & $0.0281 \pm 0.0016$ & $2.45 \pm 0.08$ & 0.86 \\
\hline 12 May & $12.47 \pm 0.55$ & $0.0205 \pm 0.0019$ & $2.31 \pm 0.16$ & 0.71 \\
\hline 12 June & $11.19 \pm 0.33$ & $0.0305 \pm 0.0025$ & $3.19 \pm 0.12$ & 0.77 \\
\hline 12 July & $11.39 \pm 0.26$ & $0.0347 \pm 0.0030$ & $2.80 \pm 0.17$ & 0.76 \\
\hline 12 August & $10.69 \pm 0.23$ & $0.0377 \pm 0.0034$ & $3.05 \pm 0.18$ & 0.75 \\
\hline 12 September & $10.15 \pm 0.28$ & $0.0398 \pm 0.0038$ & $2.78 \pm 0.16$ & 0.68 \\
\hline 12 October & $11.77 \pm 0.42$ & $0.0305 \pm 0.0030$ & $2.74 \pm 0.19$ & 0.68 \\
\hline 12 November & $13.74 \pm 0.35$ & $0.0337 \pm 0.0022$ & $2.93 \pm 0.13$ & 0.84 \\
\hline 12 December & $14.72 \pm 0.40$ & $0.0378 \pm 0.0033$ & $3.22 \pm 0.22$ & 0.75 \\
\hline 13 January & $17.92 \pm 0.55$ & $0.0313 \pm 0.0026$ & $3.53 \pm 0.24$ & 0.78 \\
\hline 13 February & $18.45 \pm 0.68$ & $0.0308 \pm 0.0025$ & $3.15 \pm 0.22$ & 0.79 \\
\hline 13 March & $18.54 \pm 0.84$ & $0.0245 \pm 0.0015$ & $2.42 \pm 0.12$ & 0.84 \\
\hline
\end{tabular}

The theoretical reported quantum yield for photosynthesis in C3 species carried out under controlled environmental conditions was $0.052-0.053 \mu \mathrm{mols} \mathrm{CO}_{2} \mu \mathrm{mol}^{-1}$ of absorbed photons at a leaf temperature of $30^{\circ} \mathrm{C}$ [52]. The maximum value of quantum yield in the present study was found to be around $20 \%$ less than the theoretical maximum, which appears to be a reliable estimate considering the actual site measurements in comparison with the controlled measurements. 


\section{Conclusions}

This paper presents the first annual assessment of the $\mathrm{CO}_{2}$ flux of the Sundarbans mangroves ecosystems, India, using the eddy covariance method, and it aids in providing more direct defensible estimates of the carbon sequestration over the Indian sub-continent. The present eddy flux tower is one of the few towers measuring $\mathrm{CO}_{2}$ fluxes in mangroves across the globe. Eddy covariance-based NEE estimates in the present study area are more reliable in comparison with previously reported estimates due to their continuous measurements throughout the year. The Sundarbans mangroves had proven to be a consistent carbon sink over different months with an annual NEP of $249 \pm 20 \mathrm{~g} \mathrm{C} \mathrm{m}^{-2}$. year $^{-1}$ during April 2012 to March 2013. A seasonal pattern of $\mathrm{CO}_{2}$ flux has been observed over the study period, indicating higher NEE during October to December 2012 and lower NEE during April to June 2012. Surface energy balance closure, which is a key indicator to the performance of the eddy covariance measurement system [11], is estimated to be $78 \%$ in the present study and is in agreement with the reported values [42]. The small bias error estimate obtained after gap-filling the missing NEE values suggests the reliable annual estimates. Our eddy covariance estimates of NEP, GPP and Re were in the range of the globally reported values from different terrestrial ecosystems. PAR was found to be a strong driver for $\mathrm{CO}_{2}$ sequestration with a maximum quantum efficiency of $0.0398 \pm 0.0038$ (95\% confidence) mols $\mathrm{CO}_{2}$ per mol of absorbed photons in September 2012. It was observed that the partitioning of net radiation into latent and sensible hear flux was uniform throughout the majority of the year, whereas during July to November 2014 the latent heat flux was higher than the sensible heat flux due to the availability of water during the monsoon and post-monsoon months. The total evapotranspiration was estimated to be $715 \pm 120 \mathrm{~mm} \cdot$ year $^{-1}$ over the study period.

The present study reports a conservative yet reliable NEP estimate of $249 \mathrm{~g} \mathrm{C} \mathrm{m}^{-2}$. year ${ }^{-1}$ purely based on half-hourly computed $\mathrm{CO}_{2}$ fluxes within the fetch of $\mathrm{EC}$ instruments and extrapolation of the same over the entire study area with the assumption of uniform homogeneous vegetation. The study does not, however, account for other important elements of aquatic pathways within which factors such as tidal and groundwater $\mathrm{CO}_{2}$ export and dissolved inorganic and organic carbon (DIC) exports can influence the NEP to a considerable degree $([17,53])$. Information on such holistic factors which drive the carbon fluxes can add value to our current estimates, which the authors envisage in future studies. Long-term research and measurements would help in building continuous and consistent eddy covariance data sets, which will help to understand the ecosystem dynamics (such as seasonal patterns), environment and climate change. Also, the understanding of inter-relationships with bio-physical variables in future studies helps in up-scaling the results the regional scales.

Acknowledgments: The present study is funded by Indian Space Research Organisation's-Geosphere Biosphere Program (ISRO-G.B.P). We duly acknowledge P. G. Diwakar, Deputy Director, NRSC for his constant support for the study. We also acknowledge the logistic support and necessary permissions extended by Shri P. Shukla, Lipika Ray, D.F.O., and Shri A. Mandal, Range Forest Officer, Sundarbans Biosphere Reserve during our field visits to the study site.

Author Contributions: All authors contributed to the data required for the manuscript. Suraj Reddy Rodda and Kiran Chand Thumaty primarily prepared the manuscript. While Chandra Shekhar Jha and Vinay Kumar Dadhwal has guided for in correcting, editing and improving the manuscript.

Conflicts of Interest: The authors declare no conflict of interest.

\section{References}

1. Stocker, T.F.; Qin, D.; Plattner, G.-K.; Tignor, M.; Allen, S.K.; Boschung, J.; Nauels, A.; Xia, Y.; Bex, V.; Midgley, P.M. Climate Change 2013: The Physical Science Basis. Intergovernmental Panel on Climate Change Working group Group I Contributions to IPCC Fifth Assessesment Report (AR5); Cambridge University Press: New York, NY, USA, 2013.

2. Canadell, J.G.; le Quéré, C.; Raupach, M.R.; Field, C.B.; Buitenhuis, E.T.; Ciais, P.; Conway, T.J.; Gillett, N.P.; Houghton, R.A.; Marland, G. Contributions to accelerating atmospheric $\mathrm{CO}_{2}$ growth from economic activity, 
carbon intensity, and efficiency of natural sinks. Proc. Natl. Acad. Sci. USA 2007, 104, 18866-18870. [CrossRef] [PubMed]

3. Magnani, F.; Mencuccini, M.; Borghetti, M.; Berbigier, P.; Berninger, F.; Delzon, S.; Grelle, A.; Hari, P.; Jarvis, P.G.; Kolari, P.; et al. The human footprint in the carbon cycle of temperate and boreal forests. Nature 2007, 447, 848-850. [CrossRef] [PubMed]

4. Beer, C.; Reichstein, M.; Tomelleri, E.; Ciais, P.; Jung, M.; Carvalhais, N.; Rödenbeck, C.; Arain, M.A.; Baldocchi, D.; Bonan, G.B.; et al. Terrestrial gross carbon dioxide uptake: Global distribution and covariation with climate. Science 2010, 329, 834-838. [CrossRef] [PubMed]

5. Donato, D.C.; Kauffman, J.B.; Murdiyarso, D.; Kurnianto, S.; Stidham, M.; Kanninen, M. Mangroves among the most carbon-rich forests in the tropics. Nat. Geosci. 2011, 4, 293-297. [CrossRef]

6. Bouillon, S.; Borges, A.V.; Castaneda-Moya, E.; Diele, K.; Dittmar, T.; Duke, N.C.; Kristensen, E.; Lee, S.Y.; Marchand, C.; Middelburg, J.J.; et al. Mangrove production and carbon sinks: A revision of global budget estimates. Glob. Biogeochem. Cycles 2008, 22. [CrossRef]

7. Chapman, V.J. Mangrove vegetation. Vaduz. J. Cramer 1976, 447-581.

8. Tomlinson, P. The Botany of Mangroves; Cambridge University Press: Cambrige, United Kingdom, 1986.

9. Robertson, A.I.; Alongi, D.M. Tropical Mangrove Ecosystems; American Geophysical Union: Washington, USA, 1992; Volume 41.

10. Twilley, R.R. The exchange of organic carbon in basin mangrove forests in a southwest Florida estuary. Estuar. Coast. Shelf Sci. 1985, 20, 543-557. [CrossRef]

11. Baldocchi, D.D.; Hincks, B.B.; Meyers, T.P. Measuring Biosphere-Atmosphere Exchanges of Biologically Related Gases with Micrometeorological Methods. Ecology 1988, 69, 1331-1340. [CrossRef]

12. Lee, X.; Massman, W.J.; Law, B.E. Handbook of Micrometeorology: A Guide for Surface Flux Measurement and Analysis; Springer: New york, USA, 2006; Volume 29.

13. Baldocchi, D.D. Assessing the eddy covariance technique for evaluating carbon dioxide exchange rates of ecosystems: Past, present and future. Glob. Chang. Biol. 2003, 9, 479-492. [CrossRef]

14. Verma, S.B. Micrometeorological methods for measuring surface fluxes of mass and energy. Remote Sens. Rev. 1990, 5, 99-115. [CrossRef]

15. Baldocchi, D. TURNER REVIEW No. 15. "Breathing" of the terrestrial biosphere: Lessons learned from a global network of carbon dioxide flux measurement systems. Aust. J. Bot. 2008, 56, 1-26. [CrossRef]

16. Wofsy, S.C.; Harris, R.C. The North American Carbon Program (NACP); Report of the NACP Committee of the U.S. Interagency Carbon Cycle Science Program: Washington, DC, USA, 2002.

17. Barr, J.G.; Engel, V.; Fuentes, J.D.; Zieman, J.C.; O’Halloran, T.L.; Smith, T.J.; Anderson, G.H. Controls on mangrove forest-atmosphere carbon dioxide exchanges in western Everglades National Park. J. Geophys. Res. 2010, 115, G02020. [CrossRef]

18. Food and Agriculture Organisation (FAO). The world's mangroves 1980-2005. 2007. http://www.fao.org/ docrep/010/a1427e/a1427e00.htm (accessed on 3 February 2016).

19. Mukhopadhyay, S.K.; Jana, T.K.; De, T.K.; Sen, S. Measurement of exchange of $\mathrm{CO}_{2}$ in mangrove forest of Sunderbans using micrometeorological method. Trop. Ecol. 2000, 41, 57-60.

20. Ganguly, D.; Dey, M.; Mandal, S.K.; De, T.K.; Jana, T.K. Energy dynamics and its implication to biosphere-atmosphere exchange of $\mathrm{CO}_{2}, \mathrm{H}_{2} \mathrm{O}$ and $\mathrm{CH}_{4}$ in a tropical mangrove forest canopy. Atmos. Environ. 2008, 42, 4172-4184. [CrossRef]

21. Chanda, A.; Akhand, A.; Manna, S.; Dutta, S.; Hazra, S.; Das, I.; Dadhwal, V.K. Characterizing spatial and seasonal variability of carbon dioxide and water vapour fluxes above a tropical mixed mangrove forest canopy, India. J. Earth Syst. Sci. 2013, 122, 503-513. [CrossRef]

22. Pan, Y.; Birdsey, R.A.; Fang, J.; Houghton, R.; Kauppi, P.E.; Kurz, W.A.; Phillips, O.L.; Shvidenko, A.; Lewis, S.L.; Canadell, J.G.; et al. A large and persistent carbon sink in the world's forests. Science 2011, 333, 988-993. [CrossRef] [PubMed]

23. Jha, C.S.; Rodda, S.R.; Thumaty, K.C.; Raha, A.K.; Dadhwal, V.K. Eddy covariance based methane flux in Sundarbans mangroves, India. J. Earth Syst. Sci. 2014, 123, 1089-1096. [CrossRef]

24. Jha, C.S.; Thumaty, K.C.; Rodda, S.R.; Sonakia, A.; Dadhwal, V.K. Analysis of carbon dioxide, water vapour and energy fluxes over an Indian teak mixed deciduous forest for winter and summer months using eddy covariance technique. J. Earth Syst. Sci. 2013, 122, 1259-1268. [CrossRef] 
25. Watham, T.; Kushwaha, S.P.; Patel, N.R.; Dadhwal, V.K. Monitoring of carbon dioxide and water vapour exchange over a young mixed forest plantation using eddy covariance technique. Curr. Sci. 2014, 107, 858-866.

26. Lloyd, C.R. Annual carbon balance of a managed wetland meadow in the Somerset Levels, UK. Agric. For. Meteorol. 2006, 138, 168-179. [CrossRef]

27. Vickers, D.; Mahrt, L. Quality Control and Flux Sampling Problems for Tower and Aircraft Data. J. Atmos. Ocean. Technol. 1997, 14, 512-526. [CrossRef]

28. Wilczak, J.M.; Oncley, S.P.; Stage, S.A. Sonic anemometer tilt correction algorithms. Bound.-Layer Meteorol. 2001, 99, 127-150. [CrossRef]

29. Moncrieff, J.B.; Massheder, J.M.; de Bruin, H.; Elbers, J.; Friborg, T.; Heusinkveld, B.; Kabat, P.; Scott, S.; Soegaard, H.; Verhoef, A. A system to measure surface fluxes of momentum, sensible heat, water vapour and carbon dioxide. J. Hydrol. 1997, 188-189, 589-611. [CrossRef]

30. Moncrieff, J.; Clement, R.; Finnigan, J.; Meyers, T. Averaging, detrending, and filtering of eddy covariance time series. In Handbook of Micrometeorology; Lee, X., Massman, W., Law, B., Eds.; Kluwer Academic: Dordrecht, Netherlands, 2004; pp. 7-31.

31. Webb, E.K.; Pearman, G.I.; Leuning, R. Correction of flux measurements for density effects due to heat and water vapour transfer. Q. J. R. Meteorol. Soc. 1980, 106, 85-100. [CrossRef]

32. Thomas, M.V.; Malhi, Y.; Fenn, K.M.; Fisher, J.B.; Morecroft, M.D.; Lloyd, C.R.; Taylor, M.E.; McNeil, D.D. Carbon dioxide fluxes over an ancient broadleaved deciduous woodland in southern England. Biogeosciences 2011, 8, 1595-1613. [CrossRef]

33. Aubinet, M.; Feigenwinter, C.; Heinesch, B.; Bernhofer, C.; Canepa, E.; Lindroth, A.; Montagnani, L.; Rebmann, C.; Sedlak, P.; van Gorsel, E. Direct advection measurements do not help to solve the night-time CO2 closure problem: Evidence from three different forests. Agric. For. Meteorol. 2010, 150, 655-664. [CrossRef]

34. Hirata, R.; Hirano, T.; Saigusa, N.; Fujinuma, Y.; Inukai, K.; Kitamori, Y.; Takahashi, Y.; Yamamoto, S. Seasonal and interannual variations in carbon dioxide exchange of a temperate larch forest. Agric. For. Meteorol. 2007, 147, 110-124. [CrossRef]

35. Zhu, Z.; Sun, X.; Wen, X.; Zhou, Y.; Tian, J.; Yuan, G. Study on the processing method of nighttime $\mathrm{CO}_{2}$ eddy covariance flux data in ChinaFLUX. Sci. China Ser. D Earth Sci. 2006, 49, 36-46. [CrossRef]

36. Reichstein, M.; Falge, E.; Baldocchi, D.; Papale, D.; Aubinet, M.; Berbigier, P.; Bernhofer, C.; Buchmann, N.; Gilmanov, T.; Granier, A.; et al. On the separation of net ecosystem exchange into assimilation and ecosystem respiration: Review and improved algorithm. Glob. Chang. Biol. 2005, 11, 1424-1439. [CrossRef]

37. Moffat, A.M.; Papale, D.; Reichstein, M.; Hollinger, D.Y.; Richardson, A.D.; Barr, A.G.; Beckstein, C.; Braswell, B.H.; Churkina, G.; Desai, A.R.; et al. Comprehensive comparison of gap-filling techniques for eddy covariance net carbon fluxes. Agric. For. Meteorol. 2007, 147, 209-232. [CrossRef]

38. Falge, E.; Baldocchi, D.; Olson, R.; Anthoni, P.; Aubinet, M.; Bernhofer, C.; Burba, G.; Ceulemans, R.; Clement, R.; Dolman, H.; et al. Gap filling strategies for defensible annual sums of net ecosystem exchange. Agric. For. Meteorol. 2001, 107, 43-69. [CrossRef]

39. Lloyd, J.; Taylor, J.A. On the Temperature Dependence of Soil Respiration. Funct. Ecol. 1994, 8, 315-323. [CrossRef]

40. Department Biogeochemical Integration at the Max Planck Institute for Biogeochemistry. New REddyProcWeb Online Tool. https://www.bgc-jena.mpg.de/bgi/index.php/Services/REddyProcWeb (accessed on 2 Feburary 2016).

41. Kljun, N.; Calanca, P.; Rotach, M.W.; Schmid, H.P. A simple parameterisation for flux footprint predictions. Bound.-Layer Meteorol. 2004, 112, 503-523. [CrossRef]

42. Wilson, K.; Goldstein, A.; Falge, E.; Aubinet, M.; Baldocchi, D.; Berbigier, P.; Bernhofer, C.; Ceulemans, R.; Dolman, H.; Field, C.; et al. Energy balance closure at FLUXNET sites. Agric. For. Meteorol. 2002, 113, $223-243$. [CrossRef]

43. Goulden, M.L.; Munger, J.W.; Fan, S.-M.; Daube, B.C.; Wofsy, S.C. Measurements of carbon sequestration by long-term eddy covariance: Methods and a critical evaluation of accuracy. Glob. Chang. Biol. 1996, 2, 169-182. [CrossRef]

44. Foken, T.; Oncley, S. Workshop on instrumental and methodical problems of land-surface flux measurements. Bull. Am. Meteorol. Soc. 1995, 76, 1191-1193. 
45. Baldocchi, D.; Falge, E.; Gu, L.H.; Olson, R.; Hollinger, D.; Running, S.; Anthoni, P.; Bernhofer, C.; Davis, K.; Evans, R.; et al. FLUXNET: A new tool to study the temporal and spatial variability of ecosystem-scale carbon dioxide, water vapor, and energy flux densities. Bull. Am. Meteorol. Soc. 2001, 82, 2415-2434. [CrossRef]

46. Hirata, R.; Saigusa, N.; Yamamoto, S.; Ohtani, Y.; Ide, R.; Asanuma, J.; Gamo, M.; Hirano, T.; Kondo, H.; Kosugi, Y.; et al. Spatial distribution of carbon balance in forest ecosystems across East Asia. Agric. For. Meteorol. 2008, 148, 761-775. [CrossRef]

47. Luyssaert, S.; Inglima, I.; Jung, M.; Richardson, A.D.; Reichstein, M.; Papale, D.; Piao, S.L.; Schulze, E.D.; Wingate, L.; Matteucci, G.; et al. $\mathrm{CO}_{2}$ balance of boreal, temperate, and tropical forests derived from a global database. Glob. Chang. Biol. 2007, 13, 2509-2537. [CrossRef]

48. Joshi, H.G.; Ghose, M. Community structure, species diversity, and aboveground biomass of the Sundarbans mangrove swamps. Trop. Ecol. 2014, 55, 283-303.

49. Simard, M.; Zhang, K.; Rivera-Monroy, V.H.; Ross, M.S.; Ruiz, P.L.; Castañeda-Moya, E.; Twilley, R.R.; Rodriguez, E. Mapping height and biomass of mangrove forests in Everglades National Park with SRTM elevation data. Photogramm. Eng. Remote Sens. 2006, 72, 299-311. [CrossRef]

50. Gilmanov, T.G.; Verma, S.B.; Sims, P.L.; Meyers, T.P.; Bradford, J.A.; Burba, G.G.; Suyker, A.E. Gross primary production and light response parameters of four Southern Plains ecosystems estimated using long-term CO2-flux tower measurements. Glob. Biogeochem. Cycles 2003, 17. [CrossRef]

51. Ruimy, A.; Jarvis, P.G.; Baldocchi, D.D.; Saugier, B. $\mathrm{CO}_{2}$ fluxes over plant canopies and solar radiation: A review. Adv. Ecol. Res. 1995. [CrossRef]

52. Ehleringer, J.; Björkman, O. Quantum yields for $\mathrm{CO}_{2}$ uptake in $\mathrm{C}_{3}$ and $\mathrm{C}_{4}$ plants dependence on temperature, $\mathrm{CO}_{2}$, and $\mathrm{O}_{2}$ concentration. Plant Physiol. 1977, 59, 86-90. [CrossRef] [PubMed]

53. Maher, D.T.; Santos, I.R.; Golsby-Smith, L.; Gleeson, J.; Eyre, B.D. Groundwater-derived dissolved inorganic and organic carbon exports from a mangrove tidal creek: The missing mangrove carbon sink? Limnol. Oceanogr. 2013, 58, 475-488.

(C) 2016 by the authors; licensee MDPI, Basel, Switzerland. This article is an open access article distributed under the terms and conditions of the Creative Commons by Attribution (CC-BY) license (http://creativecommons.org/licenses/by/4.0/). 